\title{
Physical characteristics of salt marsh sediments: ecological implications*
}

\author{
P. M. Bradley, J. T. Morris** \\ Department of Marine Science, University of South Carolina, Columbia, South Carolina 29208, USA
}

\begin{abstract}
We measured the physical characteristics of 4 sediment types commonly found in southeastern (USA) salt marshes and their relationship to sediment drainage and compressibility. Compressibility was found to be positively correlated with total silt-clay content $\left(\mathrm{r}^{2}=0.953\right)$ and negatively correlated with total sand content $\left(\mathrm{r}^{2}=0.942\right)$. A linear relationship $\left(\mathrm{r}^{2}=0.832\right)$ was found between the square root of sediment percolation velocity and bulk density. Calculations of the rate of air entry and porewater turnover based on our measurements of drainage and compressibility are consistent with the supply of $\mathrm{SO}_{4}{ }^{2-}$ necessary to support the rates of $\mathrm{SO}_{4}{ }^{2-}$ reduction found at North Inlet, South Carolina, USA, by previous researchers and indicate that compressibility may regulate the turnover of reduced end products such as pyrite. For incompressible sediments, it was demonstrated that the entry of air into sediments following water loss by evapotranspiration is quantitatively important in oxidizing reduced sulfur compounds, while drainage of compressible creek bank sediments is apparently sufficient to replace $\mathrm{SO}_{4}{ }^{2-}$ utilized by dissimilatory $\mathrm{SO}_{4}{ }^{2-}$ reducers.
\end{abstract}

\section{INTRODUCTION}

Considerable evidence indicates that hydrology is a principle process controlling many aspects of salt marsh ecology (Gardner 1973, Mendelssohn \& Seneca 1980, Hemond \& Fifield 1982, Wiegert et al. 1983, Dacey \& Howes 1984, Morris \& Whiting 1985, Howes et al. 1986). In many marshes, drainage is only significant within the narrow 10 to $15 \mathrm{~m}$ wide band of relatively tall Spartina alterniflora which borders the creeks (Gardner 1975, Nuttle 1988, Nuttle \& Hemond 1988), while in other marshes no significant drainage occurs outside of crab burrows and cracks in the sediment (Nestler 1977). In the stagnant inner marsh, which comprises 80 to $90 \%$ of the total vegetated area of North Inlet, South Carolina, USA, the primary process controlling water movement is evapotranspiration (Nestler 1977, Hemond \& Fifield 1982, Dacey \& Howes 1984, Hemond et al. 1984, Morris \& Whiting 1985 , Howes et al. 1986, Morris 1988, Nuttle 1988, Nuttle \& Hemond 1988, Nuttle et al. 1989).

In spite of its relatively low magnitude $\left(2\right.$ to $4 \mathrm{l} \mathrm{m}^{-2}$ tide ${ }^{-1}$ ), evapotranspiration (ET) can have a significant

- Contribution 785 of the Belle W Baruch Marine Institute, University of South Carolina

- Also at the Department of Biological Sciences influence on marsh sediment geochemistry. As water is lost from the sediment through ET or drainage, the resulting drop in sediment pore pressure can be alleviated by 2 mechanisms, and their relative importance depends on the characteristics of the sediment. For incompressible sediments, a drop in pore pressure sufficient to overcome the surface tension of water leads to air entry (Dacey \& Howes 1984, Hemond et al. 1984, Morris \& Whiting 1985, Howes et al. 1986, Morris 1988). In contrast, air entry does not occur in a sediment that compresses in response to a decrease in pore pressure (Hemond et al. 1984, Nuttle et al. 1989).

Given the potential significance of these divergent responses it is important to determine the extent of sediment compressibility in order to predict the impact of ET and drainage on marsh geochemistry. However, the scale of sediment height changes ( 0 to $10 \mathrm{~mm}$ ) makes in situ measurements of compression difficult (Nuttle \& Hemond 1988, Nuttle et al. 1989). Consequently, we made laboratory measurements of the compressibility of 4 distinct sediment types commonly found in southeastern (USA) salt marshes in order to determine the importance of the physical structure of sediments on compressibility. In addition, we determined the rate at which water percolated through each saturated sediment as an estimate of the upper limit of drainage in the salt marsh. 


\section{METHODS}

Site description. To develop a simple predictive model of compression as a function of sediment type, we examined 4 general types of sediment from 2 distinct marshes in North Inlet (Belle W. Baruch Marine Institute, Georgetown, South Carolina, USA) and a third marsh which borders Charleston Harbor, South Carolina, USA. Three replicate box-cores $\left(15 \times 25 \mathrm{~cm}^{2}\right.$ surface area $\times 35 \mathrm{~cm}$ depth) were collected from the high marsh and creek bank areas of the Oyster Landing site (OLHM and OLCB respectively) and the midmarsh at the Goat Island (GIMM) site in North Inlet (see Morris and Whiting [1985] for a map of the site locations at North Inlet). Sediment texture at these sites ranged from silty at OLCB to coarse sand with a low organic content at OLHM to sand with a high macroorganic content at GIMM. Box-cores were also collected from a low marsh site bordering Shem Creek (SCCB) in Charleston Harbor. In addition to box cores we collected 3 small cores (10 cm long, $4.0 \mathrm{~cm}$ ID) from each sediment type for size fraction analyses.

Sediment compression. Sediment cores were collected at each site and returned to the lab for measurement of compression. Box-cores with tightly fitting bottom caps were constructed of Plexiglas. The bottom of each box-core was beveled to provide a cutting edge for easy insertion and minimal sediment disturbance. In the field, the beveled edge of each box-core was placed on the marsh surface and the sediment was carefully cut with a sharp edging tool while the boxcore was inserted. Sediment cores which did not visibly compact during coring were excavated to minimize disturbance and were capped at the bottom. Box-cores were then sealed in plastic bags to minimize water loss during transport to the lab. In the lab the bottom of each box-core was sealed with silicon glue to eliminate water loss through drainage and to simulate the topdown' loss of water characteristic of the stagnant inner marsh. After the silicon sealant had dried, the boxcores were flooded with $35 \%$ seawater to a depth of $15 \mathrm{~cm}$. The box-cores were left flooded for $24 \mathrm{~h}$ to completely saturate the sediment.

Compression was quantified by measuring the change in height of the sediment contained in each box-core as water was lost to evaporation. Prior to the compression measurements, a millimeter scale plastic ruler attached to a plexiglas stand (total weight $<13.0 \mathrm{~g}$ ) was placed on the sediment surface. A stiff wire loop attached to a bar resting on the top wall of the box-core served as the reference point for observing changes in sediment height. After suctioning the flood water from the sediment surface, we recorded the relative scale height and measured the water lost to ET $\left(\delta_{s v}\right)$ gravimetrically for $48 \mathrm{~h}$. All compression analyses were carried out under reasonably constant ambient laboratory temperatures. Sediment compression was linear over the first 11 to $12 \mathrm{~h}$ of the experiment (Fig. 1). In this study, all sites containing compressible sediments are typically exposed to air less than $10 \mathrm{~h}$ per tide cycle.

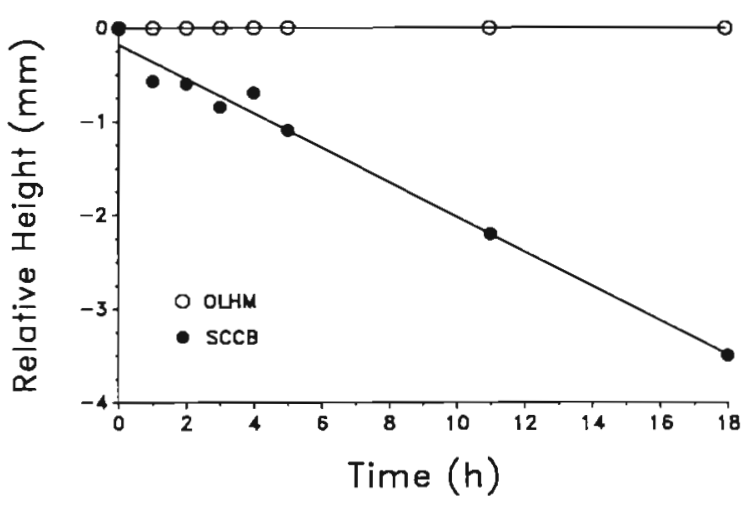

Fig. 1. Change in sediment height (compression) over time for 2 distinct sediment types

Consequently, a sediment specific compression rate was calculated as the slope of the linear regression of relative sediment height $(\mathrm{cm})$ vs time $(\mathrm{h})$ during an initial $11 \mathrm{~h}$ period. Regression coefficients $\left(\mathrm{r}^{2}\right)$ for all analyses ranged from 0.85 to 1.00 . Compressibility $(\%)$ was quantified as:

$$
\text { Compressibility }=\delta_{c} \div \delta_{w}
$$

where $\delta_{c}$ is the rate of change in sediment volume per $\mathrm{m}^{2}$ surface area as a result of compression. The compressibility $(\%)$ of a given sediment did not vary significantly with time. Compressibility, as defined in this study, is intended solely as a description of the tendancy of a sediment to demonstrate a change in volume concomitant to a loss of water.

Percolation velocity. In order to estimate the maximum rate at which water can drain through a saturated sediment during tidal exposure, we measured the sediment specific percolation velocity (analogous to a vertical seepage velocity term which has not been corrected for the porosity of the sediment) per $\mathrm{m}^{2}$ of sediment surface area. It should be emphasized that the percolation velocity term measured in this study is intended as a description of the degree to which water can move through a specific sediment type under the influence of gravity. Defined thus, the percolation velocity provides an upper-bound for water movement in marsh sediments. The actual rate of drainage in the marsh will be strongly influenced by several factors such as subsurface confining-beds and the resistance to flow between the sediment site and the creek. Subsequent to compression analysis, a $30 \mathrm{~cm}$ subcore was removed from each box-core using a $\mathrm{PVC}$ core $(4.5 \mathrm{~cm}$ 
ID) attached to a vacuum pump. Subcoring was carried out under vacuum to prevent physical compaction. The subcore was covered at the bottom with plastic screen and clamped to a ring stand. The core was immediately covered with seawater and allowed to saturate over night. Subsequently all water was suctioned from the surface and the percolation velocity was quantified as the initial linear rate of water loss from the bottom of the saturated core.

To determine the field capacity of each sediment, the subcores were allowed to stand until no further drainage occurred. Field capacity water content was then determined as the difference between final core fresh weight (FW) and dry weight (DW) after drying $5 \mathrm{~d}$ at $70^{\circ} \mathrm{C}$.

Sediment physical characteristics. Sediment bulk density and porosity were determined on a $20 \mathrm{~cm}$ subcore $(4.5 \mathrm{~cm}$ ID) which was removed from each saturated box-core, weighed to determine $\mathrm{FW}$, dried at $70^{\circ} \mathrm{C}$ for $5 \mathrm{~d}$ and reweighed to determine $\mathrm{DW}$. The sediment porosity was calculated as the volume of water per volume of sediment. The dried sediment was ground with mortar and pestle and homogenized. Two subsamples were weighed, placed in an oven at $600{ }^{\circ} \mathrm{C}$ overnight and reweighed to determine ash-free dry weight (AFDW). Total organic matter content was calculated as the percent weight loss after combustion.

Three cores $(10 \mathrm{~cm}$ length $\times 4.0 \mathrm{~cm}$ ID) were collected from the field and sequentially sieved to determine the percent composition of granules $(>2 \mathrm{~mm})$, very coarse sand ( 1 to $2 \mathrm{~mm}$ ), coarse sand $(0.5$ to $1 \mathrm{~mm}$ ) and very fine sand ( 63 to $500 \mu \mathrm{m})$. Silt ( 2 to $63 \mu \mathrm{m})$ and clay $(<2 \mu \mathrm{m})$ fractions were determined using the pipette method outlined by Day (1965). The sediment used for particle size analysis was not pretreated to remove organics. Consequently, sediment size fractions include any organic material which adhered to the surface of sediment particles. The macro-organic content was taken as the floatable sediment fraction retained by a 63 um sieve.

Statistical analyses. A one-way ANOVA procedure
(PROC GLM; SAS Inst. 1985) was utilized to evaluate significant differences in sediment characteristics between sites. The different linear regression models of compressibility as a function of sediment character were evaluated using PROC GLM (SAS Inst. 1985). The MAXR option of PROC STEPWISE (SAS Inst. 1985) was invoked to determine the combination of sediment characteristics which gave the best predictive model of the variation in compressibility. The independent variables tested were: drainage, bulk density, water content, total organic matter, macro-organic matter, all individual size fractions, total sand (very coarse sand + coarse sand + medium to very fine sand) and silt-clay $($ silt + clay $)$.

\section{RESULTS}

\section{Porosity and percolation velocity}

The mean percolation rate was $0.2 \mathrm{~cm} \mathrm{~h}^{-1}$ or less for SCCB and OLCB and did not differ significantly between these sites (Table 1). In contrast, the percolation velocity was $0.21 \mathrm{~cm} \mathrm{~h}^{-1}$ for GIMM and $1.45 \mathrm{~cm}$ $\mathrm{h}^{-1}$ for OLHM. Bulk density followed approximately the same trend across sites and increased from 0.45 at SCCB to $1.41 \mathrm{~g} \mathrm{~cm}^{-3}$ at OLHM. We examined the relationship between sediment percolation and a variety of sediment characteristics using both simple and multiple regression analyses. The best predictor of percolation rate $\left(\mathrm{cm} \mathrm{h}^{-1}\right)$ was the bulk density $\left(\mathrm{g} \mathrm{cm}^{-3}\right)$ which accounted for $83 \%$ of the variation in the square root of percolation velocity (Fig. 2).

Over time, the flux of water from the sediment approached zero as the sediment water content approached the field capacity. Although the total volume of water at field capacity differed between sediments, the field capacity water content was ca $95 \%$ of the saturation water content for all 4 sediment types. Sediment porosity ranged from a minimum of $43 \%$ at OLHM to $96 \%$ at SCCB.

Table 1. Means and standard deviations (SD) for selected sediment characteristics for each South Carolina, USA, study site. Sites are OLHM: high marsh of Oyster Landing; GIMM: mid-marsh at Goat Island; OLCB: creek bank area of Oyster Landing: and SCCB: low marsh bordering Shem Creek. Superscripts denote statistically significant subsets according to Tukey's Studentized range test $(\mathrm{p}<0.05)$

\begin{tabular}{|c|c|c|c|c|c|c|}
\hline \multirow{3}{*}{$\begin{array}{l}\text { Sediment characteristic } \\
\text { Field capacity ( } \% \text { saturation) }\end{array}$} & \multicolumn{6}{|c|}{ Study site } \\
\hline & OLHM & \multicolumn{2}{|c|}{ GIMM } & \multicolumn{2}{|c|}{ OLCB } & $\mathrm{SCCB}$ \\
\hline & $93.4^{\mathrm{d}} \quad(0.8)$ & $96.6^{4}$ & $(2.9)$ & $95.8^{\mathrm{a}}$ & $(4.5)$ & $97.1^{a} \quad(0.5)$ \\
\hline Percolation velocity $\left(\mathrm{cm} \mathrm{h}^{-1}\right)$ & $1.45^{\mathrm{a}}(1.09)$ & $0.21^{a, b}$ & $(0.09)$ & $0.01^{\mathrm{b}}$ & $(0.01)$ & $0.02^{b}(0.01)$ \\
\hline Bulk density $\left(\mathrm{g} \mathrm{cm}^{-3}\right)$ & $1.49^{\circ}(0.07)$ & $0.79^{b}$ & $(0.01)$ & $0.62^{b, c}$ & $(0.12)$ & $0.45^{c}(0.02)$ \\
\hline Porosity $(\%)$ & $43.4^{\mathrm{a}} \quad(6.6)$ & $67.7^{\mathrm{b}}$ & $(7.0)$ & $77.0^{\mathrm{b}}$ & $(1.2)$ & $96.2^{c} \quad(2.1)$ \\
\hline Total organic content (\% DW) & $1.9^{\mathrm{a}} \quad(0.4)$ & $11.0^{\mathrm{b}}$ & $(0.8)$ & $12.8^{\mathrm{b}}$ & (4.3) & $16.0^{\mathrm{b}} \quad(1.8)$ \\
\hline
\end{tabular}




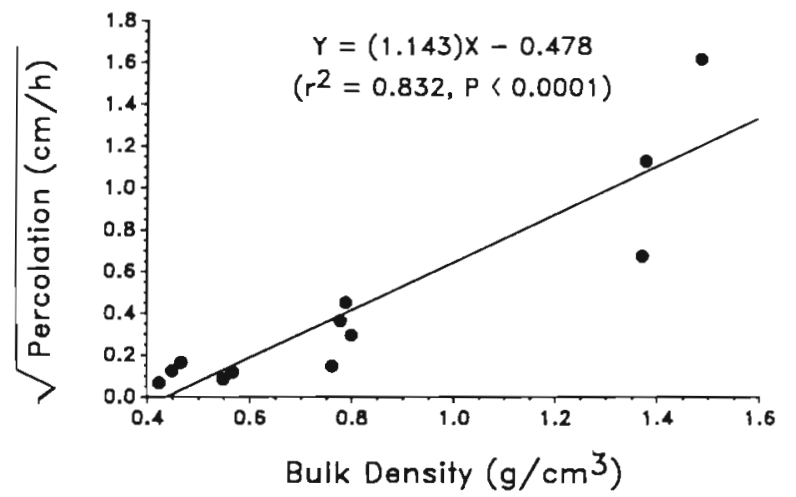

Fig. 2. Linear regression of the square root of the percolation velocity through different sediments as a function of sediment bulk density

\section{Organic content}

Total organic content ranged from a minimum of less than $2 \%$ of the sediment DW at the OLHM site to a maximum of $16 \%$ at the SCCB site (Table 1). Only $21 \%$ of the total organic content of OLHM sediments was macro-organic matter greater than $63 \mu \mathrm{m}$ in diameter. Macro-organic matter comprised 30 and $56 \%$ of the total at the OLCB and SCCB sites, respectively. In contrast, $78 \%$ of total organics at GIMM was macro-organic material.

\section{Sediment particle analysis}

Significant differences in sediment size fraction (Table 2) reveal that considerable variability in sediment composition can be found within a relatively small area in the marsh. Approximately $92 \%$ of the OLHM sediment dry weight consisted of sand size particles. The remaining $8 \%$ was silt- and clay-size particles. Similarly, $82 \%$ of the GIMM sediment was sand and $10 \%$ was silt and clay-size particles. The GIMM sediments differed from those at OLHM in that they contained $8 \%$ macro-organic material. The OLCB site contained $65 \%$ sand and $28 \%$ silt-clay size fractions. Unlike the other sites, sediment from SCCB contained only silt and clay particles $(91 \%$ ) and some macro-organic material (93\%).

\section{Sediment compressibility}

This study revealed a wide range in compressibility for the 4 sediment types examined (Table 3). Both OLHM and GIMM sediments were incompressible over the maximum period of evaporation examined during this study $(48 \mathrm{~h})$ even though sediment water loss proceeded at a rate of ca $225 \mathrm{ml} \mathrm{m}^{-2} \mathrm{~h}^{-1}$. At the other extreme, the change in volume associated with compression of SCCB sediments over the first $11 \mathrm{~h}$ accounted for the entire volume of water lost during the

Table 2. Means and standard deviations (SD) for each particle size fraction (expressed as a percentage of sediment DW) for each marsh site studied (see Table 1 for abbreviations). Superscripts denote statistically significant subsets according to Tukey's Studentized range test $(p<0.05)$

\begin{tabular}{|c|c|c|c|c|}
\hline Particle size fraction & OLSP & GIMMI & OLCB & $\mathrm{SCCB}$ \\
\hline Granule & $0.1^{\mathrm{d}}(0.0)$ & $0.0^{a} \quad(0.0)$ & $2.7^{\mathrm{b}}(1.2)$ & $0.0^{\mathrm{a}}(0.0)$ \\
\hline Very coarse sand & $2.4^{\circ}(0.3)$ & $1.5^{\mathrm{b}} \quad(0.1)$ & $1.2^{\circ}(0.2)$ & $0.0^{c}(0.0)$ \\
\hline Coarse sand & $14.2^{\mathrm{d}}(3.9)$ & $10.4^{a . b}(0.9)$ & $5.6^{b}(0.6)$ & $0.0^{c}(0.0)$ \\
\hline Medium to very fine sand & $75.1^{\prime \prime}(4.9)$ & $69.7^{a} \quad(1.0)$ & $58.4^{\mathrm{b}}(6.4)$ & $0.0^{\mathrm{C}}(0.0)$ \\
\hline Silt & $5.1^{\mathrm{a}}(0.5)$ & $4.9^{\circ} \quad(0.7)$ & $19.9^{b}(6.2)$ & $75.6^{\circ}(2.1)$ \\
\hline Clay & $2.7^{+1}(0.3)$ & $4.9^{a, b}(0.3)$ & $8.4^{\mathrm{b}}(1.4)$ & $15.3^{\mathrm{c}}(4.2)$ \\
\hline Macro-organic content & $0.4^{\mathrm{a}}(0.1)$ & $8.6^{b} \quad(1.2)$ & $3.8^{2}(1.4)$ & $9.1^{b}(2.4)$ \\
\hline Total & 1.00 .0 & 100.0 & 100.0 & 1.00 .0 \\
\hline
\end{tabular}

Table 3. Means and standard deviations (SD) for the rate of volume change due to compression (oc in $\left.\mathrm{ml} \mathrm{m}^{-2} \mathrm{~h}^{-1}\right)$, the rate of water loss $\left(\delta_{w}\right.$ in $\left.\mathrm{ml} \mathrm{m}^{-2} \mathrm{~h}^{-1}\right)$ and the compressibility $(\%)$ of the sediments for each marsh site studied (see Table 1 for abbreviations). Superscripts denote statistically significant subsets according to Tukey's Studentized range test $(p<0.05)$; ND: not determined

\begin{tabular}{|lcccc}
\hline Variable & OLHM & GIMM & OLCB & SCCB \\
\hline$\delta_{c}$ & $0.0^{a}(0.0)$ & $0.0^{d}(0.0)$ & $98.7^{b}(28.1)$ & $187.3^{c}(69.2)$ \\
$\delta_{\text {Cumpressibility }}$ & $240.0^{(\mathrm{ND})}$ & $225.8(41.1)$ & $225.4(29.9)$ & $183.6(70.2)$ \\
\hline
\end{tabular}


experiment. For the OLCB sediments, the compression volume was a constant $43 \%$ of the volume of water lost during $11 \mathrm{~h}$.

To determine which factor best predicted the variation in sediment compressibility, we linearly regressed compressibility against each of the sediment characteristics examined (Table 4). The best predictors of sediment compressibility were the various particle size fractions smaller than $2 \mathrm{~mm}$ in diameter. The regression coefficients for these ranged from 0.834 to 0.953 . The best simple linear model of compressibility was obtained using the sum of the silt and clay fractions $\left(\mathrm{r}^{2}=0.953, \mathrm{p}<0.0001\right)$ as the independent variable. Some improvement in $\mathrm{r}^{2}$ was obtained with multiple linear regression analysis of silt-clay and medium to fine sand (best 2 variable model, $\mathrm{r}^{2}=0.973$ ). Linear models containing more than 2 independent variables were plagued by cross correlation among independent variables.

\section{DISCUSSION}

This study clearly demonstrates that substantial variability in sediment characteristics can occur in a small area of the salt marsh. A sediment exhibiting $43 \%$ compressibility was collected from a site (OLCB) less than $40 \mathrm{~m}$ from completely incompressible sediments (OLHM). The North Inlet marsh system contains all 4 of the sediment types examined in this study.

The sensitivity of several marsh biogeochemical processes to sediment hydrology and the significant variability in sediment physical characteristics over relatively small spatial scales, indicate the importance of obtaining a detailed description of these properties on a site by site basis. In general, as the sediment bulk density increases, the percolation velocity increases. Bulk density accounted for ca $83 \%$ of the variation in the square root of percolation velocity (Fig. 2). The percolation rate was transformed to linearize the relationship and to reduce the variance in seepage at high bulk densities. This increasing variability in sediment water flux at high bulk densities indicates that dainage is a complex process which is influenced by microscale (the presence of fine-clay layers) and macroscale (crab burrows etc.) variations in sediment structure which cannot be accurately predicted by a single physical factor. It should be emphasized that this study did not examine a peat sediment typical of many New England marshes and the relationship between bulk density and percolation velocity may not apply to sediments outside the range of this study. Furthermore, the actual drainage rate will be influenced by the degree of sediment saturation and the resistance to flow between the inner marsh and the creek and, therefore, may differ from the potential vertical water flux that we measured in the laboratory.

Assuming that the percolation data approximates the maximum rate of vertical water movement through a given sediment exposed at low tide, the gravitational water flux through OLCB and SCCB sediments would result in the loss of, at most, $1.5 \mathrm{l} \mathrm{m}^{-2}$ over a maximum $10 \mathrm{~h}$ period of low tide exposure to air. This rate represents less than the 2 to $4 \mathrm{l} \mathrm{m}^{-2}$ tide $^{-1}$ typically lost to ET during the summer months (Dacey \& Howes 1984, Morris 1988). Moreover, percolation through the sediment will decrease as the sediment becomes undersaturated. At the other extreme, the maximum water flux through OLHM sediment would remove ca $145 \mathrm{l}$ $\mathrm{m}^{-2}$ over one $10 \mathrm{~h}$ period of low tide exposure, if it

Table 4. Coefficients for the simple linear regression of compressibility (\%) against the given independent variable. The coefficients for the best (maximum $r^{2}$ ) 2 variable multiple linear regression are also shown

\begin{tabular}{lrrrr|}
\hline Independent variable & Coefficient & Intercept & $\mathrm{r}^{2}$ & $\mathrm{P}_{\text {slope }}=0$ \\
\hline Porosity & 1.8728 & -96.6228 & 0.7453 & 0.0003 \\
Percolation velocity & -26.6262 & 47.6648 & 0.2223 & 0.1218 \\
Bulk density & -84.4059 & 105.4782 & 0.5456 & 0.0061 \\
Total organic content & 5.3073 & -19.0927 & 0.4996 & 0.0102 \\
Granule & 1.8241 & 34.9815 & 0.0029 & 0.8680 \\
Very coarse sand & -43.9401 & 92.6481 & 0.8341 & 0.0001 \\
Coarse sand & -6.8863 & 88.1354 & 0.8357 & 0.0001 \\
Medium to fine sand & -1.3327 & 103.9833 & 0.9188 & 0.0001 \\
Silt & 1.4121 & -0.5491 & 0.9351 & 0.0001 \\
Clay & 8.0137 & -25.4474 & 0.9534 & 0.0001 \\
Total silt-clay & 1.2367 & -5.4905 & 0.9415 & 0.0001 \\
Total sand & -1.1347 & 103.9267 & 0.9735 & 0.0001 \\
Total silt-clay & 3.1140 & -174.1409 & & \\
Medium to fine sand & 2.0711 & & & \\
\hline
\end{tabular}


proceeded at a constant rate. Such a water loss would represent the exchange of greater than $40 \%$ of the total water contained in $1 \mathrm{~m}^{3}$ of OLHM sediment per tidal cycle. In reality, the rate of drainage due to gravity will asymptotically approach zero as the water content approaches the field capacity $193.4 \%$ of saturation OLHM). Moreover the creek bank sediments (OLCB drainage $=1.5 \mathrm{l} \mathrm{m}^{-2}$ per $10 \mathrm{~h}$ ) would act as a barrier to drainage from the high marsh into the creek. Drainage in sandy marsh sediments may be significant only where geomorphology does not prevent drainage.

Several size fraction estimates have proven to be accurate predictors of sediment compressibility and provide a means of estimating compression in the marsh when rates of sediment water loss are known. The best of the simple linear models describes a decrease in sediment compressibility as the sand content increases $\left(\mathrm{r}^{2}=0.942\right)$ or the silt-clay fraction decreases $\left(\mathrm{r}^{2}=0.953\right)$. Using these models it is only necessary to know the rates of water loss from marsh sediments during low tide exposure in order to estimate sediment compression. Given the demonstrated lack of significant drainage at inland sites in many marshes (e.g. Gardner 1973, Nestler 1977, Nuttle 1988, Nuttle \& Hemond 1988), we can estimate the extent of sediment compression or air entry based on the rate of water loss due to evapotranspiration alone.

Based on measurements completed on 10 experimental marsh mesocosms (Morris 1988), we can estimate that evapotranspiration in North Inlet marshes varies between 0 and $5.0 \mathrm{l} \mathrm{m}^{-2}$ per $10 \mathrm{~h}$ tidal exposure (average ET $=3.0 \mathrm{l} \mathrm{m}^{-2}$ tide $^{-1}$ ). Water lost from incompressible sediments at sites like OLHM and GIMM should result in the entry of an equal volume of air. If we make the simplifying assumption that evaporative water loss proceeds from the surface until field capacity is reached and then down in a stepwise manner, then we can estimate the depth of air penetration corresponding to a water loss of $3.01 \mathrm{~m}^{-2}$ tide $^{-1}$. Our results (determined after ca $7 \mathrm{~d}$ of drainage and evaporative water loss) indicate that the total water loss at field capacity is ca 6.6 and $3.4 \%$ of the saturation water content for OLHM and GIMM sediments, respectively. Using these values as estimates of exchangeable water content for OLHM and GIMM sediments, the depth of air penetration experienced as a result of an average homogenous water loss of $3.0 \mathrm{I} \mathrm{m}^{-2}$ tide $^{-1}$ should be ca $10.5 \mathrm{~cm}$ for the OLHM site and $13 \mathrm{~cm}$ at GIMM. The presence of crab burrows, decaying plant structures and channels in the sediment should create discontinuities in air penetration and may explain the discrepancy between these calculations and the measured water table depths of $27 \mathrm{~cm}$ for OLHM (Morris \& Whiting 1985 ) and $24 \mathrm{~cm}$ at GIMM (Morris \& Whiting unpubl.)
The penetration of air to these depths should have major consequences for the growth of salt marsh vascular plants such as Spartina alterniflora. It is well-known that the growth and nutrition of $S$. alterniflora are positively correlated with sediment oxidation (Mendelssohn et al. 1981, Mendelssohn \& Postek 1982, Dacey \& Howes 1984, Howes et al. 1986) and oxygen availability (Morris 1980, 1984). Whether or not the transport of oxygen to depth in these sediments is sufficient to maintain aerobic metabolism in the belowground portion of $S$. alterniflora, this process of air entry may be a very important mechanism for the removal of volatile metabolic toxins such as $\mathrm{H}_{2} \mathrm{~S}$. It is known that the diffusion of gases through air-filled spaces is ca 4 orders of magnitude higher than through water (Nuttle 1988, Nuttle \& Hemond 1988). However, the movement of gases into or out of the sediment depends on the rate of transfer across the liquid-gas interface (Gardner in press). Although this rate of exchange is the same whether the process occurs at the sediment surface or within air-filled pores, the surface area for exchange is greatly increased by the presence of air pores. Consequently, the presence of air passages in the sediment should enhance the loss of volatiles from the sediments. This hypothesis is supported by the fact that the dissolved sulfide concentrations of the stagnant inner marsh are significantly lower in incompressible sandy substrates [Racoon Bluff Marsh, Sapelo Island, Georgia, USA; (S) $=0.03 \mathrm{mM}$, Bradley unpubl. data] than in compressible silty-clays [Airport Marsh, Sapelo Island, (S) $=3.0$ mM, King et al. 1982, Bradley \& Dunn 1989).

For completely compressible sediments such those found at SCCB, ET results in a loss of sediment volume equal to the volume of water lost. Thus plants growing in compressible sediments must depend solely on gas transport through their stems and on porewater turnover for oxygen supply to root systems. The chemical oxidation of volatile toxins such as $\mathrm{H}_{2} \mathrm{~S}$ is likely to be lower due to the lack of air entry. Moreover, compression of these sediments during tidal exposure is likely to reduce the exchange of gases with the atmosphere. For example, Asady \& Smucker (1989) demonstrated that a compression induced change in sediment bulk density from 1.1 to $1.4 \mathrm{~g} \mathrm{~cm}^{-3}$ resulted in a $42 \%$ reduction in the rate of oxygen diffusion through the sediments, while an increase in bulk density from 1.1 to $1.7 \mathrm{~g} \mathrm{~cm}{ }^{3}$ resulted in a $75^{\circ} "$ reduction in the rate of oxygen diffusion. We hypothesize that a compression of the surface layers of the marsh sediment will reduce the exchange of metabolically important gases like $\mathrm{O}_{2}$, $\mathrm{CO}_{2}$ and $\mathrm{H}_{2} \mathrm{~S}$. In the absence of significant pore water turnover, such an inhibition of gaseous exchange is expected to adversely affect the growth of Spartina alterniflora. 
Both drainage and compressibility are important regulators of marsh biogeochemical cycles. For example, sulfate reduction accounts for the degradation of a major fraction of primary production in anaerobic marsh sediments (Howarth \& Teal 1979, Howarth \& Hobbie 1982, Howes et al. 1984, King 1988), yet there must be sufficient exchange of pore water and/or oxygen entry into sediments to replenish the sulfate consumed by sulfate reducing bacteria (Garnder in press). Moreover, the end products of sulfate reduction (e.g. pyrite) must be largely oxidized since these products do not accumulate in sediments at rates equivalent to their production.

Since the GIMM sediments are incompressible (Table 3), we can assume that water lost by ET is accompanied by air entry in a manner similar to that at OLHM (Morris \& Whiting 1985). Based on marsh mesocosms (Morris 1988), we estimate that ET removes ca $790 \mathrm{l} \mathrm{m}^{-2} \mathrm{yr}^{-1}$ of water from the sediments. This rate should correspond to an entry of $158 \mathrm{l} \mathrm{m}^{-2}$ of $\mathrm{O}_{2}$ or 14 mol $\mathrm{m}^{-2}$ of oxygen in an incompressible sediment. A limited number of analyses of gas expelled from marsh sediments at sites recently inundated by high tides (Morris \& Whiting 1985) indicated that about $41 \%$ of the oxygen entering sediments by advective replacement of water loss was consumed. Thus, ca $6 \mathrm{~mol} \mathrm{~m} \mathrm{~m}^{-2}$ $\mathrm{yr}^{-1}(0.41 \times 14)$ of oxygen supplied by this mechanism is consumed by chemical or biological oxidation within the sediment.

Compared with $13.3 \mathrm{~mol} \mathrm{~m}{ }^{-2} \mathrm{yr}^{-1}$ of $\mathrm{S}$ reduced at this site by sulfate reducing bacteria (King 1988), the advection of oxygen $\left(14 \mathrm{~mol} \mathrm{~m} \mathrm{~m}^{-2} \mathrm{yr}^{-1}\right)$ in response to water loss is not sufficient to oxidize all the reduced sulfur produced at this site. Hence the enhanced loss of volatile sulfides is potentially an equally important consequence of air entry. However air entry may be important in oxidizing nonvolatile pyrite, which King (1988) estimated to account for ca $27 \%$ of total sulfate reduced. This mechanism of sediment aeration may also account for the difference in sediment inventories of chromium-reducible sulfur (which approximates pyritic sulfur) between the GIMM site and the nearby creek bank. The GIMM sediment contains significantly less pyritic sulfur than the creek bank sediment even though the GIMM site exhibits a higher rate of sulfate reduction (King 1988). Hence, the compressibility of silty creek bank sediments (Table 3 ) may reduce the oxidation of reduced end products like pyrite.

For compressible sediments where air entry is minimal, drainage is probably the dominant process that accounts for the resupply of sulfate and the removal of soluble end products of sulfate reduction. At a creek bank site in North Inlet, King (1988) estimated that the annual rate of sulfate reduction was $5.9 \mathrm{~mol} \mathrm{~m}^{-2}$ of $\mathrm{S}$. Based on the $77 \%$ porosity, (i.e. $231 \mathrm{l}$ of water per $300 \mathrm{l}$ of saturated sediment) measured at OLCB (Table 3) and a creek water concentration of $20 \mathrm{mmol}_{1} \mathrm{SO}_{4}{ }^{2-}$, we estimate that the inventory of sulfate in a volume of sediment $30 \mathrm{~cm}$ deep, assumed to be the active zone of sulfate reduction, is ca $4.6 \mathrm{~mol} \mathrm{~m}{ }^{2}$ of $\mathrm{SO}_{4}{ }^{2-}$. Therefore, the annual rate of sulfate reduction is sufficient to deplete the inventory of pore water sulfate, yet there is no evidence for sulfate depletion in these sediments (King 1988).

Since the sulfate concentration of creek bank sediments at this site is not depleted over time, some mechanism must replenish interstitial sulfate. The creek bank site (elevation $20 \mathrm{~cm}$ relative to mean sealevel) is exposed an average of $50 \%$ of the time annually (Morris unpubl. data). Consequently, a percolation velocity of $0.01 \mathrm{~cm} \mathrm{~h}^{-1}$ (Table 3 ) implies an infiltration rate of $1.2 \mathrm{l} \mathrm{m}^{-2} \mathrm{~d}^{-1}$, which is sufficient to turn over the pore water in $30 \mathrm{~cm}$ of sediment about twice annually. Note that this is far less drainage than the maximum (ca $19 \mathrm{l} \mathrm{m}^{-2} \mathrm{~d}^{-1}$ ) which would result if the sediment drained to field capacity twice daily. Moreover, this calculation does not include the localized enhanced drainage associated with crab burrows. Assuming that the infiltrating water contains $20 \mathrm{mmol}^{-1} \mathrm{SO}_{4}{ }^{2-}$, this rate of drainage supplies $8.8 \mathrm{~mol} \mathrm{~m}^{-2}$ of sulfate on an annual basis. Thus at this creek bank site drainage alone probably supplies sufficient sulfate for sulfate reduction.

The quantity of $\mathrm{O}_{2}$ delivered by water infiltrating these creek bank sediments, assuming an $\mathrm{O}_{2}$ concentration of $5.5 \mathrm{ml} \mathrm{l}^{-1}$ and a drainage rate of $1.2 \mathrm{l} \mathrm{m}^{-2} \mathrm{~d}^{-1}$, is on the order of $2.4 \mathrm{l} \mathrm{m}^{-2} \mathrm{yr}^{-1}$ or $0.2 \mathrm{~mol} \mathrm{~m} \mathrm{mr}^{-1}$ of oxygen and is, therefore, only a small fraction of that required to turnover the reduced end products. Along the creek banks, Spartina alterniflora roots can be a significant source of oxygen (Mendelssohn \& Postek 1982). Moreover, the possibility exists that these sediments are not completely compressible (e.g. OLCB Table 3) and some air entry does occur. Further, bioturbation and diffusion of $\mathrm{H}_{2} \mathrm{~S}$ and $\mathrm{O}_{2}$ contribute to the turnover of sulfides. Gardner et al. (1987) estimated that bioturbation turns over a volume of sediment along the creek banks in North Inlet equivalent to $7 \mathrm{~cm}^{3} \mathrm{~cm}^{-2}$ $\mathrm{yr}^{-1}$. Nevertheless, our estimates of drainage and air entry are consistent with rates of sulfate reduction at North Inlet, and the compressibility of sediments apparently has a significant effect on the accumulation. of the end products of sulfate reduction.

Acknowledgements. The authors gratefully acknowledge Drs L. R. Gardner and W. K. Nuttle for their critical review of the manuscript. We thank C. Coleman, Y.-H. Hwang, and $\mathrm{S}$. McAninch for their assistance with field work. We thank $\mathrm{Mr}$ and Mrs Werner for access to the Shem Creek site. This study was supported by the SC Sea Grant Consortium and the National Science Foundation (BSR-8317407). 


\section{LITERATURE CITED}

Asady, G. H., Smucker, A. J. M. (1989). Compaction and root modification of soil aeration. J. Soil Sci. Soc. Am. 53: 251-254

Bradley, P. M., Dunn, E. L. (1989). Effect of sulfide on the growth of three salt marsh halophytes of the Southeastern US. Am. J. Bot. 76: 1707-1713

Dacey, J. W., Howes, B. L. (1984). Water uptake by roots controls water table movement and sediment oxidation in short Spartina marsh. Science 224: 487-489

Day, P. R. (1965). Particle fractionation and particle size analysis. In: Black, C. A. (ed.) Methods of soil analysis. Part 1. Physical and mineralogical properties, including statistics of measurement and sampling. American Society of Agronomy, Inc., Mactison, Wisconsin, p. 545-567

Gardner, L. R. (1973). The effect of hydrologic factors on the pore water chemistry of intertidal marsh sediments. Seast Geol. 15: 17-28

Gardner, L. R. (1975). Runoff from an intertidal marsh during tidal exposure - recession curves and chemical characteristics. Limnol. Oceanogr. 20: 81-89

Gardner, L. R. (in press). Simulation of the diagenesis of carbon, sulfur and dissolved oxygen in salt marsh sediments. Ecol. Monogr

Gardner, L. R., Sharma, P., Moore, W. S. (1987). A regeneration model for the effect of bioturbation by fiddler crabs on ${ }^{210} \mathrm{~Pb}$ profiles in salt marsh sediments. J. envirl Radioact. 5 : 25-36

Hemond, H. F., Fifield, J. L. (1982). Subsurface flow in salt marsh peat: a model and field study. Limnol. Oceanogr 27: $126-136$

Hemond, H. F., Nuttle, W. K, Burke, R. W. Stolzenbach, K. D. (1984). Surface infiltration in salt marshes: theory, measurement, and biogeochemical implications. Wat. Resour. Res. 20: 591-600

Howarth, R. W., Hobbie, J. E. (1982). The regulation of decomposition and heterogrophic microbial activity in salt marsh soils. In. Kennedy, V. S. (ed.) Estuarine comparisons. Academic Press, New York, p. 183-207

Howarth, R. W., Teal, J. M. (1979). Sulfate reduction in a New England salt marsh. Limnol. Oceanogr 24: 999-1013

Howes, B. L., Dacey, J. W. H., Goehringer, D. D. (1986). Factors controlling the growth form of Spartina alterniflora: feedbacks between above ground production, sediment oxidation, nitrogen and salinity. J. Ecol. 74: 881-898

Howes, B. L., Dacey, J. W., King, G. M. (1984). Effects of sampling technique on measurements of porewater con-

This article was presented by Dr S. Y Newell, Sapelo Island, Georgia, USA stituents in salt marsh sediments. Limnol. Oceanogr. 26 : 350-360

King, G. M. (1988). Patterns of sulfate reduction and the sulfur cycle in a South Carolina salt marsh. Limnol. Oceanogr 33: 376-390

King, G. M., Klug, M. J., Wiegert, R. G., Chalmers, A. G. (1982). Relation of soil water movement and sulfide concentration to Spartina altemiflora production in a Georgia salt marsh. Science 218: 61-63

Mendelssohn, I. A., McKee, K. L., Patrick, W H., Jr (1981). Oxygen deficiency in Spartina alterniflora roots: metabolic adaptation to anoxia. Science 214:439-441

Mendelssohn, I. A., Postek, M. T (1982). Elemental analysis of deposits on the roots of Spartina alterniflora Loisel. Am. J. Bot. 69: 904-912

Mendelssohn, I. A., Seneca, E. D. (1980). The influence of soil drainage on the growth of salt marsh cordgrass Spartina alterniflora in North Carolina. Estuar. cstl mar. Sci. 11:27-40

Morris, J. T. (1980). The nitrogen uptake kinetics of Spartina alterniflora in culture. Ecology 61: 1114-1121

Morris, J. T (1984). Effects of oxygen and salinity on ammonia uptake by Spartina alterniflora (Loisel) and Spartina patens (Aiton). J. exp. mar. Biol. Ecol. 78: 87-98

Morris, J. T. (1988). Pathways and controls of the carbon cycle in salt marshes. In: Hook, D. D. et al. (eds) The ecology and management of wetlands, Vol 1. Ecology of wetlands. Croom Helm, London, p. 497-510

Morris, J. T., Whiting, G. J. (1985). Gas advection in sediments of a South Carolina salt marsh. Mar. Ecol. Prog. Ser. 27. $187-194$

Nestler, J. (1977). A preliminary study of the sediment hydrology of a Georgia salt marsh using rhodamine wt as a tracer. SEast Geol. 18: 265-271

Nuttle, W. K. (1988). The extent of lateral water movement in the sediments of a New England salt marsh. Wat. Resour. Res. 24: 2077-2085

Nuttle, W. K., Hemond, H. F. (1988). Salt marsh hydrology: implications for biogeochemical lluxes to atmosphere from estuaries. Global biogeochem. Cycles 2: 91-114

Nuttle, W. K., Hemond, H. F., Stolzenbach, K. D. (1989). Mechanisms of water storage in salt marsh sediments: the importance of dilation. Hydrolog. Proc. 3 : in press

SAS Institute, Inc. (1985). SAS user's guide: statistics. Cary, North Carolina

Wiegert, R. G., Chalmers, A. G., Randerson, P. F. (1983). Productivity gradients in the salt marsh: the response of Spartina alterniflora to experimentally manipulated soil water movement. Oikos 41, 1-6

Manuscript first received: October 5,1989

Revised version accepted: January 2,1990 